\title{
Writing the History of the Dieppe Raid: The British-Canadian Historical Liaison Relationship in Five Documents
}

\author{
Megan Hamilton
}

The work of official historian Charles P. Stacey played a foundational role in shaping the historiography of Canada in the Second World War. A lack of access to important archival material guarded by the British Cabinet Office, however, impeded Stacey's ability to produce the early histories of the war. A struggle for access lasted from late 1947 until 1950; one that would involve diplomatic maneuvering on both sides of the Atlantic. With its convoluted historical record, the 1942 Dieppe Raid acts as an interesting case study to assess the impact of this fight for information. These historical documents and the accompanying commentary highlight the challenges Stacey experienced as he navigated the British-Canadian historical liaison relationship to piece together the origins and objectives of the raid.

Les travaux de l'historien officiel Charles P. Stacey ont joué un rôle fondamental dans l'élaboration de l'historiographie du Canada pendant la Seconde Guerre mondiale. Toutefois, le manque d'accès à d'importants documents d'archives gardés par le British Cabinet Office a entravé la capacité de Stacey à produire les premières histoires de la guerre. La lutte pour l'accès, qui a duré de la fin de 1947 jusqu'en 1950, allait engager des manouvres diplomatiques des deux côtés de l'Atlantique. En raison de son bilan historique alambiqué, le raid sur Dieppe de 1942 constitue une étude de cas intéressante qui permet d'évaluer les répercussions de cette lutte pour obtenir des informations. Ces documents historiques et les commentaires qui les accompagnent mettent en évidence les défis que Stacey a dî surmonter alors qu'il étudiait les liens historiques entre l'Angleterre et le Canada afin de reconstituer les origines et les objectifs du raid.

The Northern Mariner / Le marin du nord 31, no. 3 (Autumn 2021), 313-348 


\section{Introduction}

The work of official historian Charles P. Stacey played a foundational role in shaping the historiography of Canada in the Second World War. A lack of access to important archival material guarded by the British Cabinet Office, however, impeded Stacey's ability to produce the early histories of the war. ${ }^{1}$

Until late 1947, the British Cabinet Office was generous in allowing Canadian historians access to their archives in London. In early 1948, however, the British began to place heavier restrictions on the material deemed above "military level" or private to the government. ${ }^{2}$ This tightening of access demonstrated a reluctance by the British government to release uncensored records produced during wartime. This was problematic for the Canadian Army Historical Section as some of that material directly related to the employment of the Canadian Army during the war. The struggle for access lasted until 1950 and necessitated diplomatic manoeuvring between the two governments. Previous historians, namely Tim Cook and Roger Sarty, have examined the broad history of Canadian-British historical liaison issues. ${ }^{3}$ Recently released correspondence files from the Canadian Department of National Defence, however, highlight to an even greater extent the degree to which the writing of Canada's official histories of the Second World War was bogged down by the secretive temperament of the British Cabinet Office.

The historical documents reproduced in this issue of The Northern Mariner highlight the challenges Stacey experienced as he navigated the British-Canadian historical liaison relationship to piece together the origins and objectives of the Dieppe Raid. Originally planned as Operation Rutter and set for early July 1942, intelligence concerns and poor weather caused the mission to be scrapped. However, it was soon revived as Operation Jubilee and set for August of the same year. The raiding force consisted largely of Canadian units, enthusiastic to see action after sitting idly in Britain. The raid lasted only a few hours on the morning of 19 August but resulted in fifty-five percent of the 4,963 Canadian troops becoming casualties. ${ }^{4}$ It was a devastating outcome for the first combat the Canadian Army experienced against German forces in France.

By the early 1950s, after years of work on Dieppe, Stacey was still trying to determine the original impetus for the raid, why it was resurrected after the cancellation of Rutter, and who had provided approval for Jubilee. To do so,

\footnotetext{
1 The author is indebted to Dr. Roger Sarty for the primary sources he provided, as well as the ideas and research he shared.

2 "Notes of a Meeting Held in the East Block, 1600hrs, Thursday, 29 January 1948, Between Representatives of the Department of External Affairs and Historical Section, A.H.Q," 29 January 1948, Record Group 24 [RG 24], box 31893, HQC 1450-34/336, pt. 1, Library and Archives Canada (LAC).

3 Tim Cook, Clio's Warriors: Canadian Historians and the Writing of the World Wars (Vancouver: UBC Press, 2006); Roger Sarty, "Writing the Official History of the Canadian Army in Normandy," (unpublished).

4 C.P. Stacey, Official History of the Canadian Army in the Second World War, Volume I, Six Years of War: The Army in Canada, Britain and the Pacific (Ottawa: Queen's Printer, 1955), 384-385.
} 
however, he relied on a complicated historical liaison process that forced him to depend on British historians to complete his most important archival research and that required him to ask the right questions and provide suitable guidance. These documents narrate this complex process, while showing how Stacey came to his conclusions about the origins and objects of the Dieppe Raid.

\section{Charles P. Stacey and the Army Historical Section}

In order to understand this topic properly, one must be introduced to Canada's most influential military historian, Charles P. Stacey. Born in Toronto in 1906, Stacey received a bachelor's degree from the University of Toronto. He then traveled to Britain for another bachelor's degree at the University of Oxford, which he completed at the age of twentythree. Stacey was a keen historian and decided to pursue a doctoral degree at Princeton University. He graduated in 1933, and then stayed at Princeton as an instructor until 1939 when he was appointed to the position of assistant professor. ${ }^{5}$ Stacey's dissertation focused on American, British, and Canadian military affiliations in the $1840 \mathrm{~s}-1860 \mathrm{~s}$, and was published in 1936. It was well received and two years later he began

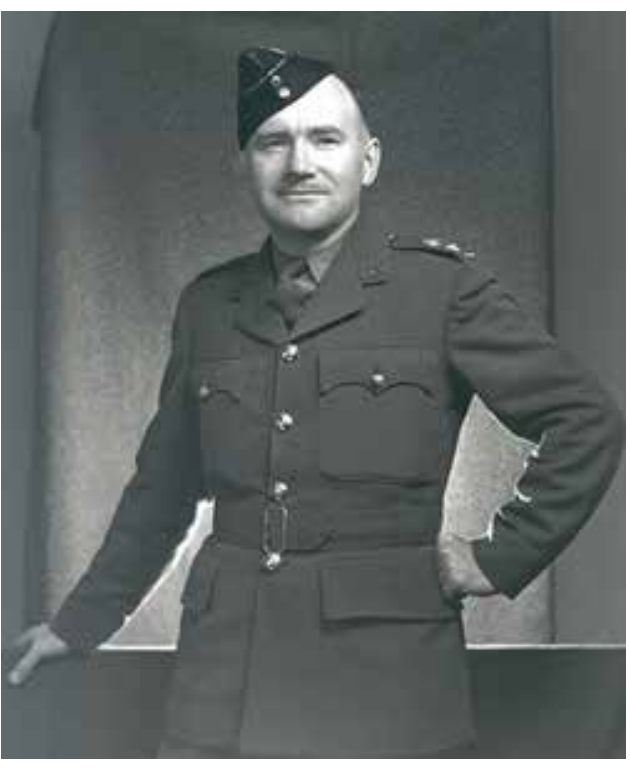

C.P. Stacey while overseas with the Canadian Army Historical Section. ("Lieutenant-Colonel Charles P. Stacey," Unattributed, c.1941-44, Library and Archives Canada, MIKAN 3239914) to write on current Canadian military affairs. $^{6}$

Stacey had an interest in the active military. He joined the University of Toronto's Canadian Officers Training Corps in his first year and then joined the actual militia the following year. ${ }^{7}$ When the war broke out in 1939, Stacey continually wrote to his old militia asking if they needed him, to which they replied in the negative. In October 1940, however, Chief of the General Staff MajorGeneral Harry Crerar offered Stacey a position as the Historical Officer of the General Staff, Canadian Military Headquarters (CMHQ) in London, with the rank of major. ${ }^{8}$ Stacey eagerly accepted and was brought back to Ottawa for training

\footnotetext{
5 C.P. Stacey, A Date With History: Memoirs of a Canadian Historian (Ottawa: Deneau, 1982), chapters $1-4$.

6 Sarty, "Writing the Official History of the Canadian Army in Normandy," 3.

7 Stacey, A Date With History, 22.

8 Stacey, A Date With History, 63.
} 
under the director of the Army Historical Section in Canada, Colonel Archer Fortescue Duguid. Duguid's reputation stemmed from being the official historian of the Canadians in the First World War. However, it had been twenty years since he started the project and he had only published one volume in two parts covering the first year of the war. Stacey knew that he could not make the same mistake, which Crerar also emphasized. ${ }^{9}$ Stacey headed to England in December 1940 with the mission of gathering the material required to craft an official history.

Due to their shared history and close relations, there was a high degree of cooperation between the fighting forces from Canada and the United Kingdom during the Second World War. This relationship extended to the historical sections of both countries as well. Stacey worked to build a strong connection with the British historians in late 1941 and 1942, which served him well later on. Britain served as Canada's overseas home base during the war and working within the central hub of the western Allied effort was key to piecing together the Canadian history. Situational structures of command, such as the organization of the Dieppe Raid and the fact that First Canadian Army fought in Northwest Europe as a part of Field Marshal Montgomery's 21st Commonwealth Army Group, meant that liaison between the historical teams of the two countries was essential to craft a comprehensive historical account.

\section{"The heaviest job of historical research": Crafting the First Wartime Narratives on Dieppe}

On 19 August 1942, Stacey was on leave in Scotland. It was a well-deserved break, as he had worked continuously for almost twenty months. When he learned of the Canadian raid that had taken place that morning, Stacey quickly put in a call to CMHQ to ask if he should cut his leave short and return to London. While his superiors did not seem overly concerned about his return, Stacey felt an urge to get to work right away. Two days later he was back in London. ${ }^{10}$ In an effort to prevent Duguid's situation, Stacey wished to follow the British method of drafting short narratives from the raw records throughout the war, which could subsequently feed into the official history. Dieppe provided him with the opportunity. ${ }^{11}$

Stacey had not previously known of the raid, but once briefed, understood that an enormous task was ahead. Until late 1942, Stacey had been working on his own. This was a minor issue while the Canadian Army was training in the UK, but now that there was increasing action to sort out, it was too much for one person. ${ }^{12}$ Stacey used the work demands imposed by the raid to convince his superiors of his need for a small staff. Of the forthcoming task, Stacey later wrote: "Dieppe provided me with the heaviest job of historical research that fell to me during the war.... Putting together documented narratives of it took up all the time I could

\footnotetext{
9 Stacey, A Date With History, 64-66.

10 Stacey, A Date With History, 87; Cook, Clio's Warriors, 99.

11 Sarty, "Writing the Official History of the Canadian Army in Normandy," 3-4.

12 Sarty, "Writing the Official History of the Canadian Army in Normandy," 3.
} 


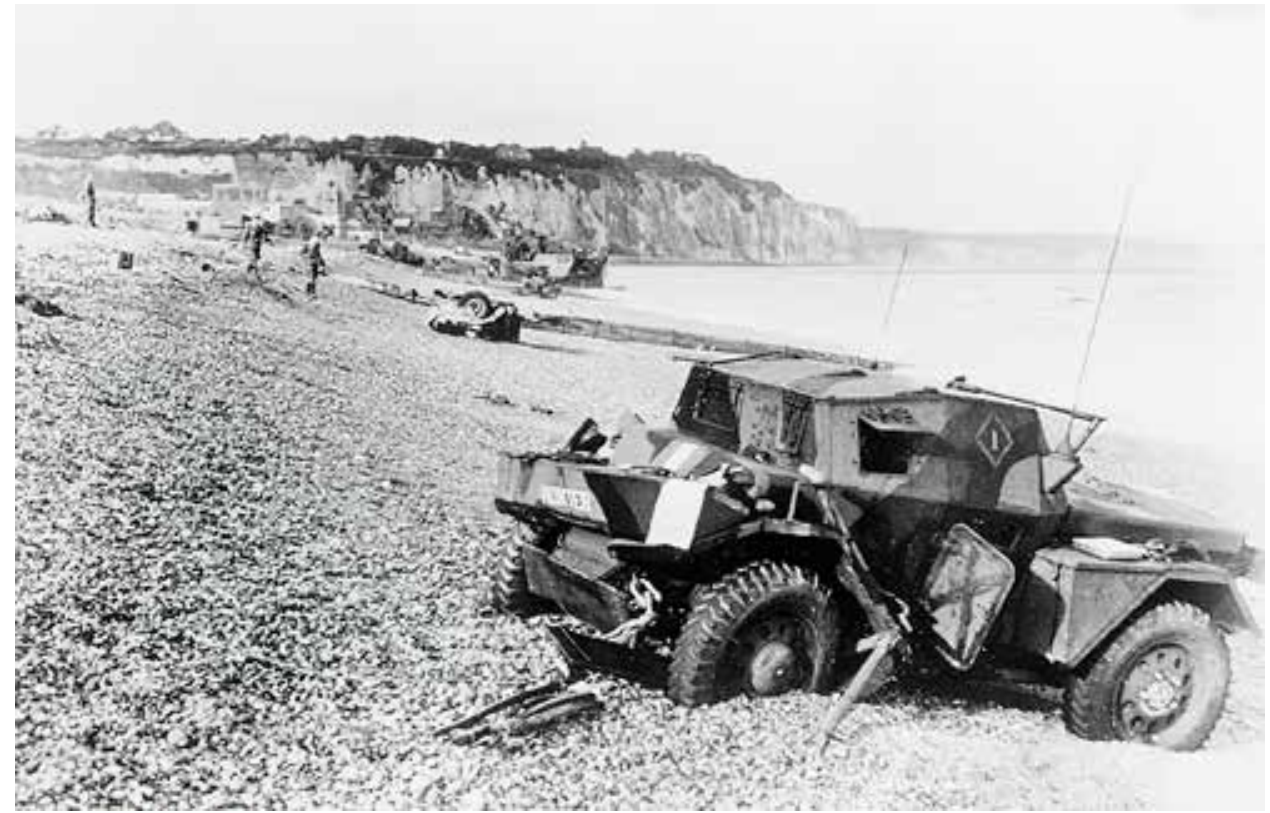

An Allied vehicle abandoned during the Dieppe Raid. ("Scout Car Abandoned During the Raid on Dieppe," Unattributed, 19 August 1942, Library and Archives Canada, Item ID 3194752)

spare from other tasks for the better part of two years."13

Stacey got to work immediately. His sources included war diaries, orders, and reports. Command had organized that each man who returned from Dieppe would write "a personal narrative of his experiences," which offered further evidence for Stacey. ${ }^{14}$ He was authorized to interview survivors, which he did for both the army and navy, as no Royal Canadian Navy historian had yet been appointed. As part of this effort, Stacey spent an evening on a battleship with Rear-Admiral HughesHallett, who had been the naval force commander during the raid. ${ }^{15}$ Using oral accounts was a logical solution to an incomplete record, despite the caveats that come with memory recollection of a traumatic event. Stacey's personal opinion on the credibility of oral testimony was unfavourable, but he did realize that there was some value to the interviews, especially when other sources were lacking. ${ }^{16}$

In progressing towards a full account of the Dieppe Raid, Stacey produced

\footnotetext{
13 Stacey, A Date With History, 97. His team of historians grew as the Canadian Army saw an increasing amount of action in the later years. Two Field Historical Sections were formed in 1944, with one heading to Italy and the other for northwestern Europe.

14 Stacey, A Date With History, 98.

15 Cook, Clio's Warriors, 99; Stacey, A Date With History, 99; C.P. Stacey, "Operation 'JUBILEE': The Raid on Dieppe 19 Aug 42. Additional Information on Planning," 5 October 1946, Canadian Military Headquarters Historical Section Report No. 159, National Defence Headquarters, Directorate of History and Heritage, http://www.cmp-cpm.forces.gc.ca/dhh-dhp/his/rep-rap/doc/cmhq/CMHQ159.pdf.

16 Tavis Harris, "C.P. Stacey and the Use of Oral Testimony in the Dieppe Narratives," Canadian Military History 21, no. 4 (2015): 68-69.
} 


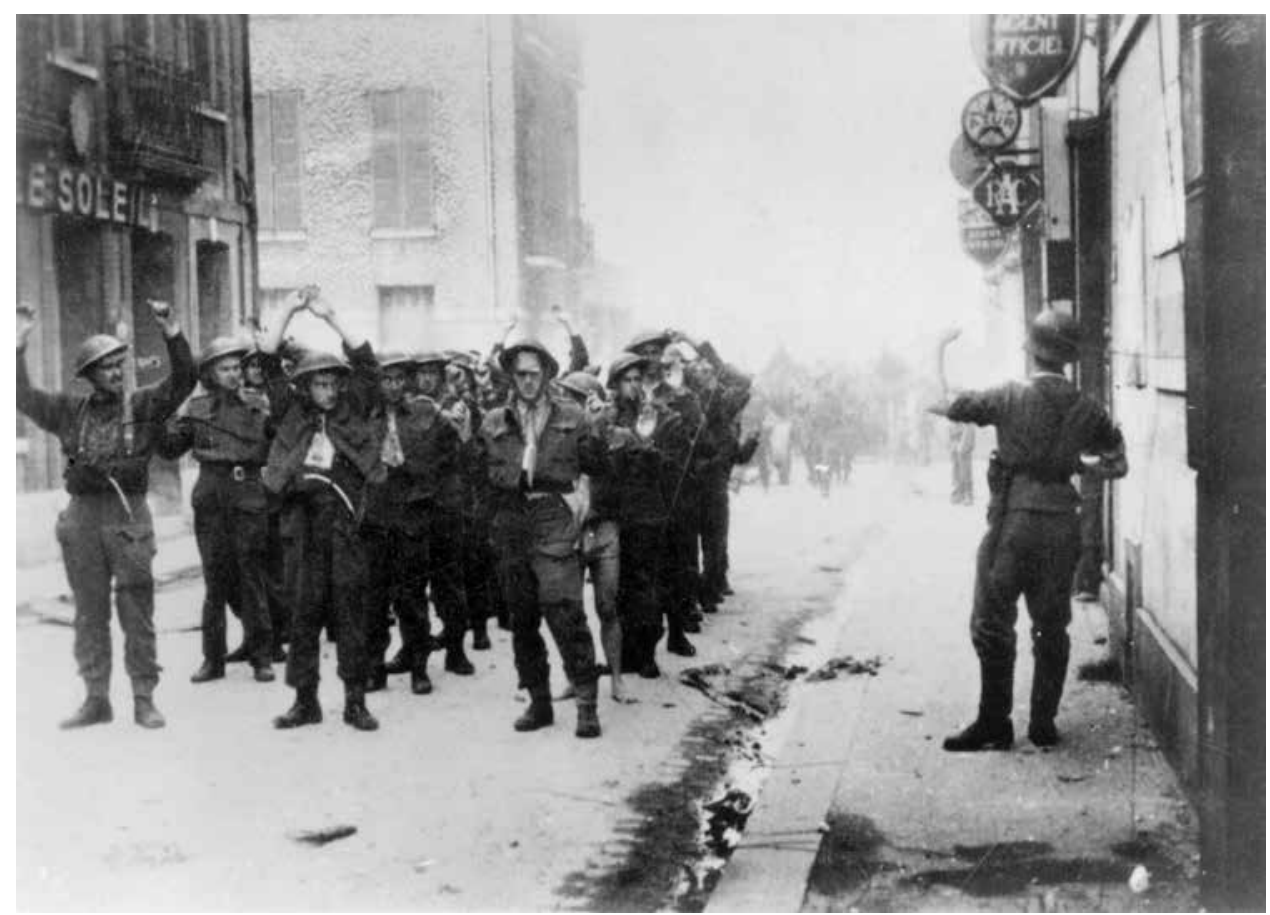

Canadian prisoners of war being marched through the city of Dieppe after the failed attack. (Library and Archives Canada, C-014171 / MIKAN ID number 3194292)

several short narratives. His first, "CMHQ Report no.83: Preliminary Report on Operation 'JUBILEE' (The Raid on Dieppe)," was complete by mid-September 1942. ${ }^{17}$ This written work proved helpful to those investigating what went wrong, which helped to convince senior officers of the value of Stacey's position. ${ }^{18} \mathrm{He}$ would produce one other narrative on Dieppe before the end of 1942, which focused on the oral testimonies he was collecting. ${ }^{19}$

Due to his strong writing skills and knowledge of the event, Stacey was tasked with two other assignments that were outside his historical jurisdiction. First, he took on the job of drafting citations and awards for the Dieppe Raid. After such a disaster, there needed to be a boost in morale for both military personnel and the civilians back in Canada. This was given such importance that General Crerar

17 C.P. Stacey, "Preliminary Report on OPERATION 'JUBILEE' (The Raid on Dieppe) 19 Aug 42," 19 September 1942, Canadian Military Headquarters Historical Section Report No. 83, National Defence Headquarters, Directorate of History and Heritage, http://www.cmp-cpm.forces.gc.ca/dhhdhp/his/rep-rap/doc/cmhq/cmhq083.pdf.

18 Cook, Clio's Warriors, 99; Sarty, "Writing the Official History of the Canadian Army in Normandy," 3.

19 C.P. Stacey, "The OPERATION at Dieppe, 19 Aug 42: Personal Stories of Participants," 31 December 1942, Canadian Military Headquarters Historical Section Report No. 89, National Defence Headquarters, Directorate of History and Heritage, https://publications.gc.ca/collections/ collection_2016/mdn-dnd/D63-4-89-1942-eng.pdf. 


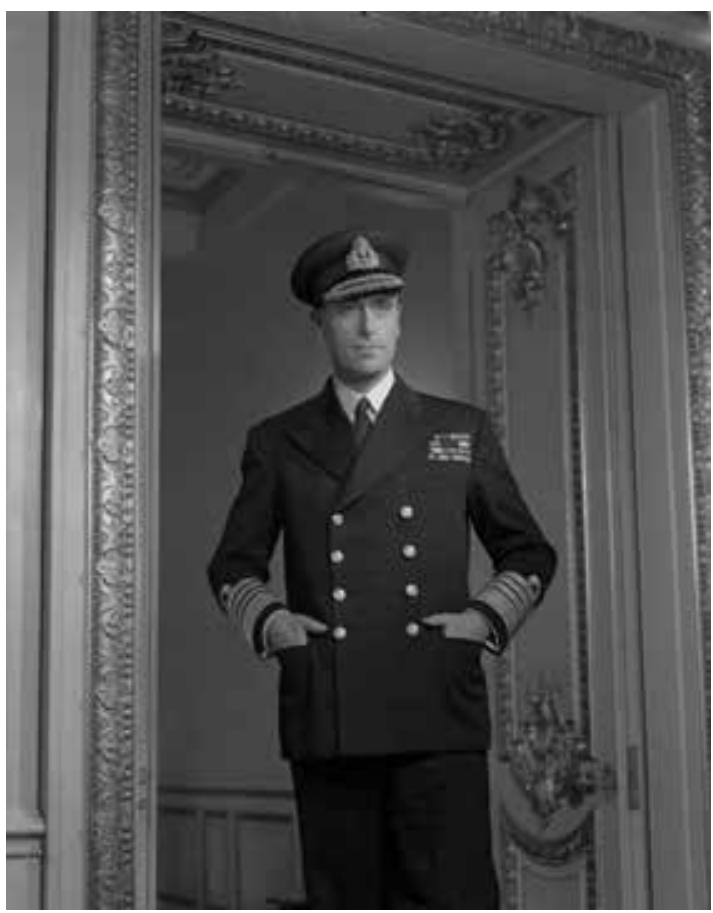

Admiral Louis Mountbatten in the fall of 1943. He had been promoted in August and appointed the Supreme Allied Commander, South East Asia Command. ("Lord Louis Mountbatten," Yousuf Karsh, 12 September-12 November 1943, Library and Archives Canada, Item ID 3511188)

involved himself in editing Stacey's drafts. ${ }^{20}$ His other additional task was to write an initial account of the Dieppe Raid for the Canadian government in early September. Although time to research and write this report was in short supply, Stacey proved up to the task, completing the account in days. While Stacey did not depict the raid as an utter failure, he was able to present a generally balanced account - despite angry comments from Vice-Admiral Louis Mountbatten, Chief of Combined Operations, deeming this to be free propaganda for the Germans. Stacey's account was positively received by the Canadian government, which gave the historian further credibility. This positive reception, along with the other valuable work he had completed, helped Stacey convince the army that the Historical Section needed to be warned of upcoming major operations. ${ }^{21}$

There was much attention given to the Dieppe Raid at the Canadian Historical Section in 1943. Stacey and his team completed seven narrative reports, the most that would be done in a single year on Dieppe. ${ }^{22}$ These reports on multiple aspects of the raid kept Stacey and his new staff busy, as did the deepening historical liaison relationship with the British, who filed a steady stream of requests for information on Dieppe. More positively, the Combined Operations Recorder

20 Roger Sarty, "The Origins of Academic Military History in Canada, 1940-1967," Canadian Military History 23, no. 2 (2015): 96.

21 Cook, Clio's Warriors, 99-100.

22 CMHQ Reports no. 90, 98, 100, 101, 107, 108, 109, see full titles here: https://www.canada.ca/ en/department-national-defence/services/military-history/history-heritage/official-military-historylineages/reports/military-headquarters-1940-1948.html. 
confidentially published a short book on the raid, which Stacey found useful in the way of sources. Further, Admiral Louis Mountbatten was transferred out of the Combined Operations Headquarters (COHQ) in August 1943, and his successor, Major-General Sir Robert Laycock, was much more approachable. Laycock gave Stacey full access to the COHQ records, which were required to conduct a thorough investigation. ${ }^{23}$

The record of Dieppe was truly a puzzle and the narrative reports helped Stacey to piece together the knowledge he had at the time. Substantial additional information was derived from captured German documents, along with pictorial and cartographical materials acquired after the 2nd Canadian Division liberated Dieppe in September 1944. Using these sources, Stacey and his team produced four more narrative reports on the Dieppe Raid in 1944-1945 and three more in 1946, before completing a final report in $1950 .{ }^{24}$ Throughout the research process, the planning of the Dieppe Raid proved particularly difficult to piece together, with Stacey and his team producing multiple narrative reports on this complicated history.

\section{Historical Liaison, Dieppe, and the Official Histories}

As it became clear that the war would be concluding in 1945, Stacey began planning for the official histories. He understood it was vital to get the plan moving along before it became a repeat of the stalled out First World War official history program. Stacey was able to gain momentum in September 1945 when he took over Duguid's position as director of the Army Historical Section. While the CMHQ remained in London until 30 September 1947, Stacey spent his first year as director traveling between London and Ottawa. ${ }^{25}$ The goal of the Canadian Historical Section was to publish a one volume summary as quickly as possible to be followed by a much more detail three volume history, all of which required direct access to the available documents in London. ${ }^{26}$ Again following a British model, Stacey recommended a five-year plan for the Canadian official histories, which his superiors approved. Unfortunately, as the military demobilized and significantly cut their budget, Stacey lost some of his best historians to the booming university sector. Understanding their importance to the successful completion of the official histories, Stacey fought hard to keep the rest of his team together. ${ }^{27}$

Stacey's team found an advantage in the fact that they were able to remain located

\footnotetext{
23 Stacey, A Date With History, 98-99.

24 CMHQ Reports no.116, 128, 130, 142, 153, 159, see full titles here: https://www.canada.ca/ en/department-national-defence/services/military-history/history-heritage/official-military-historylineages/reports/military-headquarters-1940-1948.html; AHQ Reports no.10, 36, see full titles here: https:/www.canada.ca/en/department-national-defence/services/military-history/history-heritage/ official-military-history-lineages/reports/army-headquarters-1948-1959.html.

25 Stacey, A Date With History, 171, 178.

26 Sarty, "Writing the Official History of the Canadian Army in Normandy," 8.

27 Sarty, "Writing the Official History of the Canadian Army in Normandy," 7.
} 


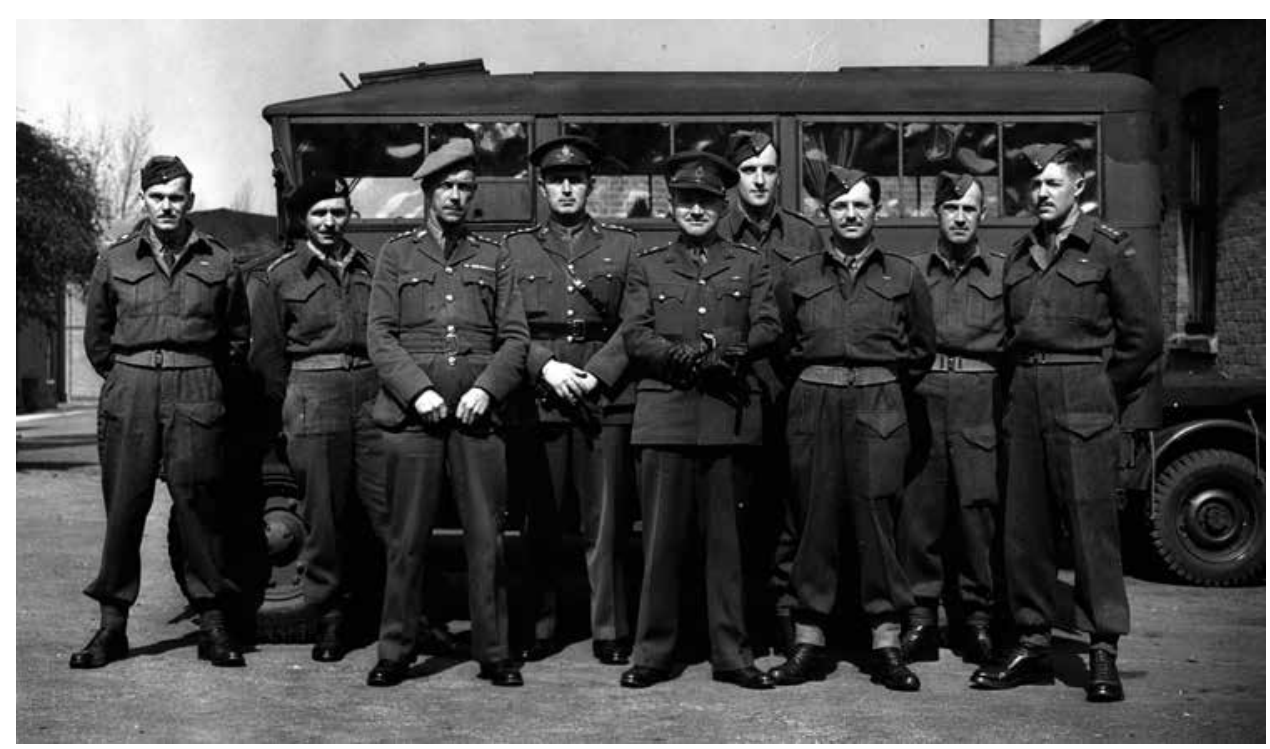

Members of the CMHQ Historical Section in London, England, 19 April 1944. Stacey stands in the very centre. ("Personnel of the Canadian Military Headquarters Historical Section, London, England," Private R.W. Hole, 19 April 1944, Library and Archives Canada, MIKAN 3221307)

in London for more than two years after the war concluded in Europe. The British Cabinet Office established an archive for the records of the British Army, which became the "second home" for the Canadian historians as they hurried to complete their one volume official summary. ${ }^{28}$ The strong relationship Stacey had established with the British Historical Branch paid off and the Canadians were welcomed in the British archives. By early 1946, however, the British began to realize that there was sensitive information that could not be freely published. On 19 July 1946, they issued a memorandum with a blanket procedure for access to British documents that applied to all Dominion historians. These protocols established that any work containing reference to British records had to be submitted to British authorities before publication. Additionally, the most significant point on the memorandum was a paragraph that declared all records above "military level" to be restricted access. In order to access the information of these high-level files, Dominion historians had to submit a questionnaire through their High Commissioner, which the British would then respond to after researching their records. ${ }^{29}$ This was not good news for Stacey and his team, as they were attempting to complete their narratives and summary volume as quickly as possible. Nonetheless, in December 1946 they had agreed to the terms and offered reciprocal procedures for British

28 Sarty, "Writing the Official History of the Canadian Army in Normandy," 8.

29 "Provision of Information from UK Records to Accredited Dominion Histories: Note by the Cabinet Office," 19 July 1946, RG 24, box 31893, HQC 1450-34/336, pt. 1, LAC. It must be noted that this memorandum said nothing of American or Combined Chief of Staff records. 
historians wanting access to Canadian files. ${ }^{30}$ Despite the previously mentioned agreement and a productive working relationship between the British and Canadian historical teams, Stacey began to notice a negative shift in early 1947.

The Historical Section was hard at work in early 1947 when Stacey began to face a specific stubbornness from the British. In reference to the memorandum of 19 July 1946, the Canadians had requested that the British define "military level," as they urgently needed to know which files they could or could not freely examine. This was essentially refused by the British, but they did mention that if they were to define it, "military level" would only be up to and including the war diaries at the army headquarter level.

An example they gave that particularly concerned the Canadians was that of the 21st Army Group, with which the First Canadian Army had fought in Northwest Europe. The files from the 21st Army Group's headquarters were considered to be property of both the US and the UK, as it was a force under the Combined Chiefs of Staff. Due to their dual ownership and inclusion of Cabinet-level files, like personal letters between Prime Minister Churchill and Field Marshal Montgomery, these records were to be restricted to the questionnaire method until they could be sorted. ${ }^{31}$ Stacey was unsatisfied with this answer, as he believed that the Canadians were entitled to the records of the headquarters that their army had fought under. The British, however, were not looking to negotiate informally and requested that the issue be left alone. Such a strong refusal left a sour note with Stacey, and it was clear that the Canadian-British historical liaison relationship was heading down a bumpy path. The Canadian historians had to be wary of pushing the matter too strongly, as they had to keep their options open for future requests. Unaware of the storm that was coming, a senior staff member of the Department of External Affairs wrote: "In practice, however, I do not feel that there should be any great difficulty in dealing with requests [for Combined Chiefs of Staff records]...."32

Adding to any potential dilemmas, the CMHQ was dissolved as of 30 September 1947. The Canadian Army's Historical Section was relocated back to Ottawa, while a single historical liaison officer remained in London. LieutenantColonel Gerald Nicholson held the position for a short time, and was later replaced by Captain Murray Hunter, who remained until the spring of 1951. Hunter would have his work cut out for him.

With Stacey, Nicholson, and the rest of the Historical Section in Ottawa, Hunter's position was important for maintaining historical liaison with the British. It was of value to have a Canadian representative with direct access to unrestricted British documents, which made for a smoother research process. Stacey gave Hunter the task of sorting out the narrative of Operation Overlord, amongst his other liaison tasks. Hunter found that he needed access to three specific files above "military level" in late October 1947. He attempted to ask the British authorities

30 Riddell to Robertson, 19 December 1946, RG 24, box 31893, HQC 1450-34/336, pt. 1, LAC.

31 Robertson to St. Laurent, 8 May 1947, RG 24, box 31893, HQC 1450-34/336, pt. 1, LAC.

32 Riddell to Robertson, 12 June 1947, RG 24, box 31893, HQC 1450-34/336, pt. 1, LAC. 
for them informally, but they replied that he must follow protocol and use the questionnaire method, or have Ottawa formally request them through diplomatic channels. ${ }^{33}$ The necessary steps for the latter option were performed, but two of the files were not passed on until early February 1948. The third file took even longer, as the British were sure that the Canadians already had a copy. Thus, only after a thorough search of the Canadian archive confirmed what Stacey already knew, did the British release the third document. ${ }^{34}$ This situation caused delays for the Canadian history program. The summary volume was not released until early 1948, slightly over a year later than Stacey had hoped it would be completed.

The preface of the Official Historical Summary states its purpose to give the people of Canada access "at as early a date as possible an authentic comprehensive outline of the work of their Army in the War of 1939-1945...." 35 It was meant to be a brief summary so that Canadians could appreciate the Canadian Army's contribution to the Second World War. Stacey tells his readers that this summary has in no way exhausted the Allied records and has only just scratched the surface of the German records. Due to the time that had passed since the fateful day on 19 August 1942, however, the Dieppe narrative was quite fleshed out already. Stacey admits that the thirty-seven pages (two chapters) given to all aspects of Dieppe was unbalanced when compared to the coverage of other events, but he felt that the available details should be provided to the public without delay. ${ }^{36}$ The first project was complete, leaving the Historical Section to switch their focus to the much more detailed three volume series.

Despite the publication of the summary, much historical work remained to be done. Stacey grew increasingly concerned that the British policies around access to historical documents would continue to delay Canadian progress.

\section{Conference Confrontation with the British}

A conference of US and Commonwealth military historians held in Washington in February 1948 provided Stacey with the opportunity to discuss his concerns with British counterparts. In a summary memorandum to Chief of the General Staff, Lieutenant-General Charles Foulkes, Stacey explained:

The fact of the matter is that the British have been extremely difficult about granting us access to high-level documents, and whenever the matter has been brought up in conversation they always remark that such access by us would require American concurrence. The Americans, on the other hand, whether through policy or inadvertence, have always given me to understand that they consider Canada a partner in "combined holdings" of

\footnotetext{
33 Mills to the Under Secretary of External Affairs, 20 October 1947, RG 24, box 31893, HQC 1450-34/336, pt. 1, LAC.

34 McKay to Stacey, 4 February 1948, RG 24, box 31893, HQC 1450-34/336, pt. 1, LAC.

35 C.P. Stacey, The Canadian Army, 1939-1945: An Official Historical Summary (Ottawa: King's Printer, 1948), vii.

36 Stacey, An Official Historical Summary, viii.
} 
documents, and I have been informally assured that we can have access to the [Supreme Headquarters Allied Expeditionary Force] papers. We have in fact lately received from the US Department of the Army a clearance for a visit by [the Deputy Director of the Historical Section] to work in those papers. ${ }^{37}$

To facilitate discussion on these issues, Stacey extended an invitation for the British to visit Ottawa while they were in North America for the conference. UK Chief Military Historian, Dr. James Butler, politely declined, citing a need to keep the trip brief. Instead, he proposed a separate meeting of Commonwealth historians while everyone was already in Washington, which Stacey accepted. ${ }^{38}$ The Canadian historian suspected that Butler and his team would push the Americans towards a more restrictive policy.

Several days before Stacey and Nicholson were set to leave for the conference, they held a meeting with three senior staff members of the Department of External Affairs. The purpose was to secure the backing of External Affairs for Stacey's planned confrontation with the British, adding it to the support he had already received from the Minister of National Defence, Brooke Claxton. The meeting was successful in getting External Affairs onside. ${ }^{39}$ Action was also taken by Foulkes, who sent a memorandum to the British High Commissioner to Canada, Sir Alexander Clutterbuck, explaining the situation and expressing concern. ${ }^{40}$ Nonetheless, the forthcoming conference would be the critical point in AngloCanadian historical relations.

By the time of the conference, Stacey and his team were in the middle of their most detailed historical research, and they needed a liberal access policy from the British. Before leaving on 2 February, Stacey typed up a list of his "proposed points of discussion." ${ }^{41}$ His points of focus were accessing Allied and enemy documents, the exchange of drafts, and the terms of publication. Illuminating Stacey's priority was his very first point, which highlighted the need to ensure that: "Historians accredited by any military services of each Government have access to all the combined records which were produced in the operation of the Headquarters in which two or more of the Allies participated." 42

The first couple of days of the conference were devoted to an American

\footnotetext{
37 "Access to Historical Information - UK and US," 16 January 1948, RG 24, box 31893, HQC 1450-34/336, pt. 1, LAC.

38 Butler to Stacey, 5/12 January 1948, RG 24, box 31893, HQC 1450-34/336, pt. 1, LAC.

39 "Notes of a Meeting Held in the East Block, 1600hrs, Thursday, 29 January 1948, Between Representatives of the Department of External Affairs and Historical Section, A.H.Q," 29 January 1948, RG 24, box 31893, HQC 1450-34/336, pt. 1, LAC.

40 "Memorandum: Access to Documents for Historical Purposes," 30 January 1948, RG 24, box 31893, HQC 1450-34/336, pt. 1, LAC.

${ }^{41}$ "Proposed Points of Discussion with British Historians," February 1948, RG 24, box 31893, HQC 1450-34/336, pt. 1, LAC.

42 "Proposed Points of Discussion with British Historians," February 1948, RG 24, box 31893, HQC 1450-34/336, pt. 1, LAC.
} 
display of their historical program and archives, with the important discussions not occurring until the afternoon of 6 February. This first round of discussions began the dive into the key issues of the conference. Firstly, the British classification of the $21^{\text {st }}$ Army Group HQ as Cabinet-level combined records surprised the Americans, who did not consider them to be so. This was in Stacey's favour, as the British agreed rather quickly to downgrade the files. Unfortunately, this proved one of the conference's few moments of agreement between the Canadians and British. The second topic of the afternoon was the issue of restricted access to combined records. Straight away the British declared that they could not be opened to any historians, other than the official historical teams of the UK and US. In response, Stacey made it clear that the Canadians could not agree to lock themselves out of files that related to their own fighting forces. ${ }^{43}$ The discussion was then put on pause until the next day.

The tense discussion on combined records continued in the morning on 7 February. With an American representative presiding over the meeting, the delegates drafted a paper to present to the Combined Chiefs of Staff on the issue of historical access. It was largely based on the list of recommendations that Stacey had brought to Washington. Unfortunately, the British sensitivity to the subject prevented the paper from recommending that all Dominion historians be welcomed into the combined records. Stacey negotiated with Brigadier H.B. Latham, head of the British Army Historical Branch, for some time, but to no avail. Latham accused Stacey of going back on the questionnaire method they had agreed to in 1946-1947, but Stacey argued that there had been no mention of combined records on that document. Latham insisted that it was implied, but Stacey did not back down from his position. Knowing that Stacey respected the privacy of Cabinet papers, Latham came in from a different angle and argued that the combined files were intermixed with Cabinet-level files. ${ }^{44}$ Latham then proposed that Stacey apply formally to the British government. This debate concluded with a decision to not include it in detail on the paper currently being crafted, but only to say that it was being dealt with through other channels..$^{45}$

In the same meeting, the American historians brought up the topic of referencing combined records. They feared that without proper and complete citations their

\footnotetext{
43 "Notes on Matters Discussed During Meeting of US and Commonwealth Military Historians, Washington, DC, 4-7 Feb 48," 13 February 1948, RG 24, box 31893, HQC 1450-34/336, pt. 1, LAC. 44 The Americans had their Cabinet-level papers separated from their combined records. They were also quite willing to provide the Canadians access to their archives, which occurred in a small quantity both before and after the 1948 Washington conference. However, when this fight was still going on in 1950 and the Canadians proposed just doing the research in Washington, the British were hesitant to allow it; "Memorandum of Discussion on Combined Records, Held in Mr. Sedwick's Room at Commonwealth Relations Office, London, at 1530 HRS, 22 Aug 50," 22 August 1950; Claxton to Pearson, 5 February 1950; "Note on Access to 'Combined Records' for Canadian Official Historians," 4 May 1950, RG 24, box 31893, HQC 1450-34/336, pt. 1, LAC.

45 "Notes on Matters Discussed During Meeting of US and Commonwealth Military Historians, Washington, DC, 4-7 Feb 48," 13 February 1948, RG 24, box 31893, HQC 1450-34/336, pt. 1, LAC.
} 
official histories would lack legitimacy when scrutinized by American scholars. Stacey supported them on this point. They also hoped to refute the writings of some private individuals who were making unwarranted claims. Continuing to be the inflexible party at the meeting, the British declared that they followed a policy of not citing any documents that were not accessible to the public. They did finally promise to take the American request to their government, but Stacey noted that "it seemed fairly clear that [the British] championship of the American idea would not be particularly warm." 46

The British tried to use their seniority again in the next topic that was brought up, which was access to German records. The British and Americans both held complete copies of the collections, and number of the documents from the British holdings had been loaned to Canada. The British attempted to suggest that the Dominion historians should submit requests for German information through London, instead of the current procedure of loaning out entire files. In regard to this case study, this suggestion would have consequences on the Canadian ability to study the Dieppe Raid from the German perspective, which was vital. Stacey refused to agree to this, while the Americans would not abandon their policy of loaning out German records. Stacey lightly snubbed the British delegation by stating that his team's narratives based on the loaned German documents would be available to any Dominion historians who requested them. ${ }^{47}$

After the meeting concluded, Stacey had to return to his commitments at Queen's University, leaving Nicholson as the sole Canadian representative. Before his departure, however, Lieutenant Clark from the US delegation spoke to Stacey privately. He expressed surprise at the issue regarding combined records, as the Americans had always considered Canada to be entitled to these files. Just before the conference, the US authorities had granted clearance to Nicholson to examine the Supreme Headquarters Allied Expeditionary Force (SHAEF) records in Washington. Clark reassured Stacey that this commitment would be honoured, despite the conference proceedings. In his reflection of the conference, Stacey wrote that the Americans were generally more supportive of the Canadian position. The opposing force was always the British delegates, who consistently "[dwelled] on the 'dangers' involved in a more liberal policy." 48 Interestingly, the representatives from the other Dominions were generally passive participants for most of the conference. Unfortunately, this left Nicholson essentially on his own in the fight for liberal access at a meeting of the Commonwealth historians on 8 February.

The meeting of Commonwealth representatives dealt with a number of points.

\footnotetext{
46 "Notes on Matters Discussed During Meeting of US and Commonwealth Military Historians, Washington, DC, 4-7 Feb 48," 13 February 1948, RG 24, box 31893, HQC 1450-34/336, pt. 1, LAC. 47 "Notes on Matters Discussed During Meeting of US and Commonwealth Military Historians, Washington, DC, 4-7 Feb 48," 13 February 1948, RG 24, box 31893, HQC 1450-34/336, pt. 1, LAC. 48 "Notes on Matters Discussed During Meeting of US and Commonwealth Military Historians, Washington, DC, 4-7 Feb 48," 13 February 1948, RG 24, box 31893, HQC 1450-34/336, pt. 1, LAC.
} 
Important to this study was a reluctance from the British and South Africans to draw conclusions and lessons from such recent historical events. LieutenantColonel Agar Hamilton of South Africa claimed that the purpose of these official histories was to provide the facts, rather than a fleshed out historical interpretation. Nicholson replied that the Canadian histories would most certainly be drawing conclusions on the Dieppe Raid, which speaks to the attack's importance to the Canadian experience of the war. The historians from New Zealand also intended to analyze their failures from the war. The topic of access to German records was brought up once again, and while it was decided that the other Dominions would request information or certain files, Nicholson was able to hold the British to the current loaning procedure for the Canadians. ${ }^{49}$ Thanks to Nicholson standing firm at the Commonwealth meeting in Washington, Stacey had German files to draw from. In regard to the Dieppe Raid, these files allowed him to conclude that the Germans did not have advanced knowledge of the attack. Nonetheless, this fact remains a lingering controversy, which speaks to Dieppe's persistence in the modern literature. ${ }^{50}$

The Commonwealth meeting concluded without real mention of the combined records, but the British were not done throwing their weight around. On 9 February, the delegates from the Dominions, including Nicholson, were taken on a recreational tour of Gettysburg by the US government. While they were out, the British and American representatives deliberately had a private meeting to rework the paper from 7 February. The result was the "Coordination of Official War Histories" document that would be the bane of Stacey's existence for the next few years. Nicholson did not see the revised document until 12 February when an American officer shared it with him. Immediately expressing concern, Nicholson knew that Canada could not agree to the terms it set out. ${ }^{51}$

Paragraph three "A" of the document dealt with access to combined records. It gave free rein to British and American historians while Dominion historians had to be approved by both countries each time they requested information. The most underhanded part of the revised document was that it had been completed without the approval of Dominion historians, yet stated their agreement in the document's introductory remarks. ${ }^{52}$ Nicholson sent urgent word to Stacey and confirmed with the Americans that the Canadians would take the issue up directly with the British. ${ }^{53}$

\footnotetext{
49 "Notes of Meeting of Representatives of Military Historical Sections of the UK and the Dominions held in the Shoreham Hotel, Washington, at 1000 hours, Sunday, 8 Feb 48," 8 February 1948, RG 24, box 31893, HQC 1450-34/336, pt. 1, LAC.

50 Cook, Clio's Warriors, 186-187; For more on the controversy over German advanced knowledge, see John P. Campbell, Dieppe Revisited: A Documentary Investigation (London: Frank Cass, 1993).

51 Claxton to Heeney, 20 March 1950, RG 24, box 31893, HQC 1450-34/336, pt. 1, LAC.

52 "Coordination of Official War Histories," February 1948, RG 24, box 31893, HQC 1450-34/336, pt. 1, LAC.

53 Nicholson to Stacey, 14 February 1948, RG 24, box 31893, HQC 1450-34/336, pt. 1, LAC.
} 


\section{The Diplomatic Dance for Documents}

This "family squabble", as American Major General Ward called it, continued through 1948, 1949, and $1950 .{ }^{54}$ Stacey was forced to jump through all kinds of diplomatic hoops as the British purposely stalled. They made a number of excuses, but the truth was that they feared "political bombshells that might be lurking in the millions of pages of unprocessed material." ${ }_{55}$ The Canadian Department of External Affairs was involved frequently, as were the British and Canadian High Commissioners. A message between the two Prime Ministers was suggested on several occasions, but was left as a last resort. All of this was occurring while Stacey was attempting to complete the three detailed volumes of Canada's official histories. As Tim Cook has highlighted, what angered the Canadians further was that private individuals, such as unofficial historian Robert Sherwood, had already been given access to restricted files. ${ }^{56}$

Eventually, ongoing pressure from the Canadian government and Stacey's continued efforts paid dividends. After Stacey took a trip to London in AugustSeptember 1950 to engage with his British counterparts, they finally compromised. They agreed to Stacey's most urgent demand, which was access to the proceedings of major Allied conferences during the war. Other combined records would remain under the special application protocol. ${ }^{57}$ Upon returning from Europe, Stacey wrote to Foulkes that "it is now safe to assume that the long controversy over combined records has now terminated in a satisfactory manner." ${ }^{88}$ Unfortunately, Stacey felt that the British still did not recognize Canada's right to the combined records, but he decided that it was not worth pursuing further. ${ }^{59}$ Nonetheless, the progress that Stacey achieved, with the support of the Canadian government, was an important stand for freedom of information and historical accuracy.

\section{The Documents: Piecing Together Dieppe}

Following the British compromise in the fall of 1950, the Canadians enjoyed a period of fairly productive and cooperative historical research. A.B. Acheson of the British Historical Branch became a key contact point for Stacey, and he submitted many questions to Acheson. In regard to the Dieppe Raid, Stacey was chiefly concerned with which details of the planning the British had record of, considering the incomplete paper trail he had seen thus far. Since many of the necessary files were combined records, Stacey was forced to use the questionnaire method instead of sending Hunter's successor, Major Cunningham, to search the archives. He and Acheson liaised through the spring of 1953 on this issue, focusing on the approval

\footnotetext{
54 Ward to Stacey, 13 September 1950, RG 24, box 31893, HQC 1450-34/336, pt. 1, LAC.

55 Sarty, "Writing the Official History of the Canadian Army in Normandy," 11.

56 Cook, Clio's Warriors, 181.

57 Brook to Stacey, 18 October 1950, RG 24, box 31893, HQC 1450-34/336, pt. 1, LAC.

58 “Combined Records," 23 September 1950, RG 24, box 31893, HQC 1450-34/336, pt. 1, LAC.

59 “Combined Records,” 23 September 1950, RG 24, box 31893, HQC 1450-34/336, pt. 1, LAC.
} 
of Operations Rutter and Jubilee, Churchill's involvement in the process, and Dieppe's connection to Sledgehammer - the proposed Allied invasion of Germanoccupied France in 1942. Acheson proved helpful by providing thorough answers to Stacey's inquiries, although he also determined that the written record for the planning of the raid was minimal. ${ }^{60}$

In October 1950, Stacey submitted a questionnaire to Norman Brook, Secretary of the British Cabinet, that focused heavily on the Dieppe Raid (Document 1). The two had met earlier in the year, when Brook explained that, while Churchill had planned to discuss the Dieppe Raid in detail in his history, The Hinge of Fate, he had changed his mind, instead covering the attack in two pages and referring the reader to Stacey's 1948 The Canadian Army 1939-1945: An Official Historical Summary for more information (Mountbatten had convinced Churchill to remove a more critical account of the raid). ${ }^{61}$ With Churchill's account providing no new information on the raid's origins, Stacey's questions to Brook were aimed at establishing the high-level decision-making that led to approval for the attack. In particular, he wished to know if there had been an exchange between Churchill and Stalin on the subject of raiding, when Churchill and the War Cabinet had approved the revised Dieppe Raid, and what had been discussed during a small high-level conference that the Prime Minister had convened at No. 10 Downing Street in June 1942 to seek opinions on the Dieppe operation.

A.B. Acheson took over two years to reply to the questions Stacey had sent Brook. This delay pushed Stacey to inquire with Admiral Hughes-Hallet about Churchill's June 1942 meeting about Dieppe. The naval officer also took a notable amount of time to respond, but he confirmed with his diary that the date of the meeting was 30 June 1942. Churchill had recently returned from the US and had expressed concern about proceeding with the Dieppe Raid due to the recent disaster at Tobruk (Document 3). When Acheson finally replied to Stacey (Document 2), he explained that after an "exhaustive search," he had found no telegrams between Churchill and Stalin in this period on the subject of raiding, nothing about the revived raid in the War Cabinet records, and no direct record that the Chiefs of Staff had formally approved the revived operation, which indicated to Acheson that Mountbatten had secured direct approval for the raid from the Prime Minister. ${ }^{62}$

\footnotetext{
60 Acheson to Stacey, 1 April 1953; "Raiding Operations Policy, 1941-1942," April 1953, RG 24, box 31893, HQC 1450-34/336, pt. 2, LAC.

${ }_{61}$ "Memorandum of Interview with Sir Norman Brook, Secretary of the Cabinet," 15 September 1950, RG 24, box 31893, HQC 1450-34/336, pt. 1, LAC. Churchill's original draft was much different than the two pages that ended up being published. He wrote that Mountbatten was responsible for the revival of Rutter into Jubilee. On 1 September 1950, he sent the draft to Mountbatten for approval, who immediately became defensive and rewrote the section. By the time it got back to him, Churchill had become uninterested and moved on, leaving the Dieppe narrative very much incomplete and free of any blame on Mountbatten. For more, see David Reynolds, In Command of History: Churchill Fighting and Writing the Second World War (New York: Basic Books, 2007), 344-347.

62 Acheson to Stacey, 19 January 1953; Stacey to Acheson, 23 January 1953, RG 24, box 31893, HQC 1450-34/336, pt. 2, LAC.
} 
In March, Stacey followed up on the answers provided by Acheson with another questionnaire, which attempted to locate information on the initial origins of the Dieppe Raid in the spring of 1942 (Document 4). He explained his motivation to Acheson: "In order to make our account of the preliminaries of Dieppe as complete as possible, we are anxious to have an exact picture of the chronology of decisions." ${ }^{63}$ Less than a month later, Acheson sent a lengthy reply (Document 5), in which traced the origins of the raiding policy to 1941 when pressure began to mount for action on the Western front, particularly from the Soviet ambassador and British politicians. Information collected on the city and port of Dieppe was substantial enough by April 1942 to begin concrete planning, which paralleled American ideas for action. Acheson provided Stacey with a relatively detailed summary of the raid's origin, including how it fit into the planning for Operation Sledgehammer, and discussions with the Americans, most likely understanding by that point that the Canadian historian was determined to solve the puzzle.

\section{Shaping the Historiography}

In the fall of 1955, Stacey published Six Years of War: The Army in Canada, Britain and the Pacific - the first of the three-volume official Canadian history of the war. ${ }^{64}$ Dieppe held a notable place in this first detailed volume. A total of two chapters and 112 pages covered all aspects of the event, including Operation Rutter and the revival, German defences, the actual raid and all five landings, the losses on both sides, how the public was told, and the influences on German strategy. Some sections were carried over from the 1948 narrative, though this version boasted further detail, more topics, and some new information. ${ }^{65}$ Stacey argued that Dieppe was not a complete waste, as lessons learned were applied in the invasion of France two years later. However, he stopped before agreeing with Mountbatten's comment that "the battle of Normandy was won on the beaches of Dieppe." ${ }_{66}$

Stacey also drew several conclusions on the origins and objects of the Dieppe Raid based on the available evidence, including the answers provided by Acheson. He traced the raid's origins to discussions held in early April 1942. He explained its primary purpose as a test of large-scale amphibious operations and what was considered in 1942 to be the most pressing problem of an invasion operation: the immediate capture of a major port. Stacey noted Churchill's June 1942 private conference on Dieppe from which the Prime Minister had come away convinced of the raid's necessity. He also explained Rutter's cancellation in early July and the revival of the plan soon after, explaining that, "The cancellation of the Dieppe project had caused deep chagrin at Combined Operations Headquarters, and there is no doubt that it was the staff of C.O.H.Q. that was responsible for the

\footnotetext{
63 Stacey to Acheson, 12 March 1953, RG 24, box 31893, HQC 1450-34/336, pt. 2, LAC.

64 Cook, Clio's Warriors, 183-185.

65 Stacey, Six Years of War, 325.

66 Stacey, A Date With History, 101-102.
} 
revival." Other motivating factors identified by Stacey included the public outcry in Allied countries for action at this point in the war, "considerations of morale," and the continued German advances in Russia that made it "essential to give any diversionary aid possible to our Soviet allies." Stacey explained that during a conversation between General Andrew McNaughton - then the commander of Canadian First Army - and Mountbatten on 25 July 1942, the Chief of Combined Operations had stated that the Prime Minister and the War Cabinet had approved the revived raid, now known as Operation Jubilee, although the historian noted that the "reference to the War Cabinet was a misunderstanding." ${ }^{67}$ In describing the murkiness of the Dieppe paper trail, Stacey explained that,

Although the Dieppe Raid is in general a very well documented operation, the documentation with reference to its origins and objects - points of special importance - is far from complete. In these matters the historian is obliged to rely to a considerable extent upon the memories and the verbal evidence of informed persons. The fact that "security" was of such great importance militated against complete records being kept. ${ }^{68}$

The documents featured in this issue of The Northern Mariner highlight Acheson's influence on the Canadian narrative of the Dieppe Raid. Stacey had to depend on the British interpretation of the evidence and was forced to take Acheson's word as fact. Without access to the British archival holdings, Acheson's letters became Stacey's primary sources. The Canadian historian's interpretation was limited to what the British revealed. Given the information that other historians have been able to mine from the UK's National Archives over the last four decades, it is likely that Stacey's account of the Dieppe Raid would have been more detailed if he would have been allowed firsthand access to the archives. It was postwar politics that created this dynamic, a less than ideal situation when writing the foundational narrative of an event. In 1982, Stacey published a memoir of his time as a historian, titled $A$ Date With History: Memoirs of a Canadian Historian, which further emphasized his struggle in piecing together the origins and planning of the Dieppe Raid. ${ }^{69}$ Time and distance allowed him to speak more freely of the liaison dilemma, providing a behind the scenes perspective on the saga. Stacey passed away in 1989 , leaving the history of the Dieppe Raid to other historians. ${ }^{70}$

67 Stacey, Six Years of War, 325-346.

68 Stacey, Six Years of War, 326.

69 Stacey, A Date With History, 100.

70 With open access to the archives, other historians have built on or challenged Stacey's interpretation of the origins of the Dieppe Raid. While the Raid has been a consistent feature in the historiography of the Second World War, key studies came in 1989 by Brian L. Villa and 1996 by Peter J. Henshaw. Villa's book, Unauthorized Action: Mountbatten and the Dieppe Raid, argues that Mountbatten is to blame because he never obtained formal approval to relaunch Operation Rutter - a thesis that diverges from prior studies. In contrast, Henshaw, a student of Villa's, argued that Canadian nationalism could be blamed for the rebirth of Operation Rutter and the launch of Operation Jubilee, pointing out that Canadian generals had agency and autonomy ("The Dieppe Raid: A Product of Misplaced Canadian Nationalism?" The Canadian Historical Review 77, no. 2 (1996): 250-266). With opposing arguments, the two scholars published a conversational debate 
The Dieppe Raid occurred within a matter of hours on 19 August 1942, yet has left decades of controversy as its legacy. Stacey was the first to research the event in-depth, but the planning of the Dieppe Raid was complex and left few written records. His work was further hindered by the British decision in 1948 to restrict access to the sections of their archives deemed above "military level" and the subsequent need to converse through the questionnaire method. The difficulty of writing a foundational narrative solely based upon another's interpretation is demonstrated through the documents shared in this issue of The Northern Mariner. The acknowledgment of Acheson's influence on Stacey's narratives of the Dieppe Raid is vital to understanding the development of the historiography surrounding the raid.

Megan Hamilton is a master's student in the Department of History at the University of Waterloo, Ontario, Canada. (Contact: m24hamil@uwaterloo.ca)

\section{The Documents}

\section{Document 1}

\section{C.P. Stacey to Norman Brook, "Information Requested by Canadian Army Official Historian from UK Records 'Above Military Level'," 24 October 1950, RG 24, box 31893, HQC 1450-34/336, pt. 1, Library and Archives Canada.}

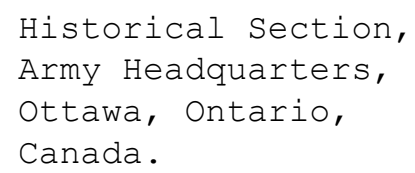

article in 1998, titled: “The Dieppe Raid Debate," (The Canadian Historical Review 79, no. 2 (1998): 304-315). Both Villa and Henshaw state in the article that this debate still has life to it and that future historians should continue the investigation. In 2013, David O'Keefe joined the debate with his book One Day in August: The Untold Story behind Canada's Tragedy at Dieppe, arguing that the Raid was motivated by the British need to steal material relating to the German Enigma machine. Otherwise, the Dieppe debate has not seen any real bombshell publications on the Raid's origins and approval. That does not mean that the debate has been settled, but few other historians have taken a solid run at the mess that Stacey and Villa dealt with, despite a wider access to documents now available. Instead, the last two decades have produced popular histories, broad surveys, and journal articles dealing with more niche topics. For further discussion of the historiography of the Dieppe Raid, see Megan Hamilton, "Writing the History of the Dieppe Raid: Historical Liaison and its Influences" Minerva 7 (June 2021): 3-25. 
release of the record of the Casablanca Conference. We are most grateful for the arrangements that have been made, and I note the conditions on which this release is authorized.

I imagine that the Americans will make no difficulty about releasing the records of the other conferences, as I heard some time ago from my opposite number in Washington that there was no disposition there to put any obstacles in our way.

During our conversations while I was in London you were good enough to suggest that I might send to you personally any requests, dealing with matters of a policy nature, for information from high-level United Kingdom records. I am accordingly taking the liberty of attaching to this letter a questionnaire indicating certain points of interest to us. I should be most grateful if you could have these points investigated and such information as exists and can be released forwarded to me. It may well be that it is not practicable to give us everything we ask for, and in that case there will be no complaint.

It may be that Question 1, relating to communications with Stalin, is answered in Mr. Churchill's new volume, which has just begun to appear here in serial form.

With respect to Question 3, Mr. Churchill's Dieppe chapter, which you were good enough to show me, does not refer to such a specific conference concerning Dieppe as I believe to have taken place, although his general statements are fully in accordance with our understanding of what took place at this meeting. It is my impression that Mr. Churchill's account somewhat "telescopes" the events; as I remember it, it seemed to indicate that his consultations on the matter took place at a date only shortly before the actual execution of the raid on 19 August 1942. My belief is that the meeting referred to took place in June, and that the operation discussed was "Rutter", the original version of the raid which was cancelled early in July. The operation was revived in a slightly different form a week later.

Please allow me to say once more how much we appreciate your assistance, and to apologize for taking advantage of your kind offer to the extent which is done in this letter.

Yours sincerely,

C.P.S. 
Sir Norman Brook, KCB,

Cabinet office,

Great George Street, S.W. 1,

London, England.

INFORMATION REQUESTED BY CANADIAN ARMY OFFICIAL HISTORIAN FROM UNITED KINGDOM RECORDS "ABOVE MILITARY LEVEL"

QUESTION 1

On 25 July 1942, shortly after the revival of the project for the Dieppe raid, Lt-Gen. A.G.L. McNaughton had a conversation with Vice-Admiral Lord Louis Mountbatten, which General McNaughton recorded in part as follows:

It appears that Stalin had cabled the Prime Minister asking what was being done to distract the Germans by raiding. The Prime Minister had been very pleased to be able to reply indicating action was in hand and in consequence he had approved the highest priority in preparation for J[ubilee].

Is there any record of an exchange of cables between Mr. Churchill and M. Stalin at this period on the subject of raiding? If such cables exist, we should be grateful for copies of or extracts from them, or summaries of their same.

QUESTION 2

In the same conversation of 25 July 1942 Lord Louis Mountbatten told General McNaughton that the Prime Minister and the War Cabinet had approved the revived Dieppe project, though the War Cabinet had not been told the place or date.

On what date did the War Cabinet approve this project? Do the United Kingdom cabinet records contain any information which would throw light on the reasons for the revival of the raid project, or the reasons which led the War cabinet to give its approval?

\section{QUESTION 3}

Is there any formal or informal record of the discussion of the Dieppe raid project understood to have been held by Mr. Churchill at No. 10 Downing street soon after his return from the United States in June 1942 (i.e., probably on or about 27 June)? It is our understanding that on this occasion the Chief of the Imperial General Staff 
(General Sir Alan Brooke) advised that the raid should be carried out. We should like to know what the record (if any) shows in this connection. Lord Ismay is believed to have been present. It is of course possible that security considerations prevented any record of this meeting from being kept.

\section{$\underline{\text { QUESTION } 4}$}

Careful examination of Canadian records indicates that the United Kingdom Government at no time suggested, either formally or informally, the employment of Canadian Army forces in the Middle East. We should be interested in knowing whether there are any British records which throw light upon the apparent desire of the British Government that the Canadian formations should remain in Britain. It has occurred to us that this may be related to the malicious propaganda which represented it as British policy "to fight all our battles in the Middle East only with Dominion troops" (Mr. Churchill to General Auchinleck, 17 Sep 41, The Grand Alliance). Is there any evidence on this point?

Specifically, was there any discussion in the summer of 1942 of allotting Canadian formations to Operation "TORCH" (the invasion of North Africa)? If so, would it be possible to indicate the considerations that influenced the British Government against suggesting such employment?

\section{Document 2}

\section{A.B. Acheson to C.P. Stacey, 19 January 1953, RG 24, box 31893, HQC 1450- 34/336, pt. 2, Library and Archives Canada}

CABINET OFFICE, Great George Street, London, S.W.1.

\section{January 1953.}

My dear Colonel,

I am now able to write to you about the first of three questions you put to Sir Norman Brook.

I enclose a note which has been prepared after an exhaustive search through the records. 
Question 1

There are no telegrams on record at this period between Mr. Churchill and Stalin on the subject of raiding. I have little doubt that the statement which the Prime Minister had made to M. Maisky on the evening of the $23^{\text {rd }}$ July is the origin of the statement which Lord Louis Mountbatten made to General McNaughton on the $25^{\text {th }}$ July.

\section{Question 2}

You will see from the note enclosed that there is nothing in the records of the War Cabinet about the revived Dieppe project. If it had actually been before the War cabinet, I should have expected to find some mention of it. The War Cabinet discussed highly secret matters almost daily. They had special procedure for limiting the circulation of the records of such discussions. It seems improbable that, if this matter had come before them, no record would have been made.

On the other hand, if the decision was taken by the Prime Minister, the absence of any record becomes much more intelligible. You have of course seen Captain Allen's correspondence with Major Cunningham, which gives Lord Louis Mountbatten's recollection that he went personally to the Prime Minister and obtained his approval. I am disposed to think that the silence of the War Cabinet papers tends to confirm this recollection.

Incidentally, there is no direct record that the chiefs of Staff as such formally approved the revived operation. At their discussion on the $20^{\text {th }}$ July they were informed by Lord Louis Mountbatten of the circumstances in which he had put forward a proposal that he should be responsible for launching "the next large-scale raiding operation". And it is clear from the reference to Captain Hughes-Hallett later in the minutes of this discussion that this operation was the revived Dieppe raid. Of course, if the Chiefs of Staff had thought that the raid was unwise it would have been their duty to say so then, and the fact that they did not implies their approval. The probability is that they gave their approval directly and that the somewhat cryptic form of the record is explained by Lord Louis Mountbatten's request (recorded by Captain Allen in his correspondence with Major Cunningham) that when he raised the matter with the Chiefs of Staff he particularly asked that no written record should be kept. 
There is no record of any discussion of this nature at the end of June. You will have observed that Lord Louis Mountbatten thinks that this conversation took place in July and related, not to the original project, but to the revived one. Again, it seems to me that the records, such as they are, tend to bear this out. By the $11^{\text {th }}$ June the original proposal had passed the Chiefs of Staff, the Prime Minister, and the War Cabinet. What could have intervened between then and the $27^{\text {th }}$ June to cause the Prime Minister to review the matter? Not his conversations in the United States, which were concerned with major strategic questions. It is true that the Chief of Combined Operations had felt it necessary to postpone the project for a fortnight so that a second exercise could be carried out. But this had been successful. It is also true that there had been some question of a security leak. But again this had been investigated and dismissed. And there is no particular reason in any case to suppose that either of these matters had even come to the Prime Minister's knowledge.

But the revived operation was a different matter. The Prime Minister's consent to it was in any case necessary. His mind had been much more occupied with other matters in the interval. What is more natural than that he should have thought it necessary to go into the whole question again personally? Moreover, if this discussion had taken place in June with Lord Ismay present, I cannot help feeling that some note would have been made of it, however brief, for there was at that time no special reason to refrain from making the usual records. But in July Lord Louis Mountbatten was laying great emphasis on the need to have no written records.

I hope all this will be of use to you. The suggestions I have made above are of course only personal inferences, and you will doubtless wish to consider them and form your own judgement about them, but I think you can take it that the facts about what the records contain are comprehensive and accurate.

I will write again as soon as possible about your Question 4 .

Yours ever,

[signed] A.B. Acheson

Colonel C.P. Stacey, 
Historical Section,

Army Headquarters,

Ottawa,

Canada

\section{OPERATIONS "RUTTER" AND "JUBILEE"}

On the $16^{\text {th }}$ June, 1942, Mr. Churchill warned Stalin that there were indications of a German move against Murmansk and invited Stalin's views on possible joint Anglo-Russian operations in that area. To this Stalin replied on the $20^{\text {th }}$ June that he thought such operations desirable, and he asked what British forces could be made available. There was then an interval in the correspondence until Mr. Churchill sent Stalin the long telegram of $17^{\text {th }}$ July reviewing the prospects in regard to convoys, joint operations in the north, and the possibility of operations on the Russian southern flank, which is printed on pages 238-241 of "The Hinge of Fate".

Stalin's reply to this telegram, dated the $23^{\text {rd }}$ July, is also printed in "The Hinge of Fate", and until the Dieppe raid was launched towards the end of August little more of importance passed between Mr. Churchill and Stalin, except some communications about another convoy projected for september and about the arrangements for the Prime Minister's visit to Moscow in August.

On the other hand, there had of course over a long period been repeated representations from Russia for large-scale operations in the west as a means of bringing relief to their own hard-pressed forces. In April 1942 the War Cabinet considered the question of offensive operations against the continent primarily in this context. They concluded that raiding operations should be undertaken during 1942 to test German defences, as a preliminary to more extensive operations later.

On the $13^{\text {th }}$ May the Chiefs of Staff approved an outlined plan for "Rutter" as a basis for detailed planning by the Force Commanders.

On the $6^{\text {th }}$ June the Chiefs of Staff reviewed the preparations for offensive action against the continent and their recommendations included one that "Rutter" should take place at the end of June, but that, if weather conditions were unfavourable, it should be cancelled and not 
postponed until July, since the assault craft and shipping would be required for another projected operation, namely "Imperator". This recommendation was put before the Prime Minister.

On the $11^{\text {th }}$ June the Prime Minister informed the War Cabinet that "Rutter" would take place shortly, and that as a result of his intervention "Imperator" had been cancelled. At this meeting the Prime Minister said that he had the previous evening handed M. Maisky a paper outlining our proposals for assisting Russia, which had included a statement that we should continue the policy of raids against selected points on the continent as a means of preventing the Germans from transferring troops from the west to the east.

On the Prime Minister's return from the United States he gave Cabinet an account of his discussions with the President and his advisors at a meeting on the $27^{\text {th }}$ June. "Rutter" was not mentioned at the meeting.

On the $16^{\text {th }}$ June Lord Louis Mountbatten informed the Chiefs of Staff that "Rutter" had been postponed for two weeks.

On the $22^{\text {nd }}$ June the Chiefs of Staff had a discussion about a possible security leak in relation to "Rutter".

On the $24^{\text {th }}$ June the Chiefs of Staff agreed that the operation should proceed.

After several 24-hour postponements the Chiefs of Staff were advised by Lord Louis Mountbatten on the $6^{\text {th }}$ July of a further postponement, and agreed with the advice he gave that if the operation did not take place on the date then proposed (presumably $8^{\text {th }}$ July) the force should be disbanded and consideration given to mounting the operation again at a later date.

On the $20^{\text {th }}$ July the Chiefs of Staff discussed a proposal put forward by Lord Louis Mountbatten that he should be responsible as Chief of Combined Operations for mounting and launching "the next large-scale raiding operation". The record merely states that Lord Louis Mountbatten explained the circumstances which had led him to put forward this proposal. The Chiefs of Staff deferred consideration of it, but took note that the First Lord agreed to Captain J. Hughes-Hallett acting as the Naval Force Commander "for this operation". 
On the $24^{\text {th }}$ July the War Cabinet considered Stalin's

telegram to Mr. Churchill of the previous day. This telegram had been handed to the Prime Minister by M. Maisky the previous evening, and the Prime Minister said that in the course of conversation he had told M. Maisky that heavy raids on the continent would be carried out in the near future.

On the $27^{\text {th }}$ July the Chiefs of Staff approved a general procedure for operations for which the Chief of Combined Operations was responsible, under which the latter was to be responsible for launching such operations in consultation with the necessary authorities and subject to the Naval Commander-in-Chief's approval.

\section{Document 3}

\section{C.P. Stacey to A.B. Acheson, 23 January 1953, RG 24, box 31893, HQC 1450- 34/336, pt. 2, Library and Archives Canada.}

Historical Section,

Army Headquarters,

Ottawa, Canada,

23 January 1953.

Dear Mr. Acheson,

Very many thanks for your letter of $19^{\text {th }}$ January. The new information which it gives me is very timely, and I am most grateful.

The question of the date of Mr. Churchill's conference on Dieppe has now been settled. Some time ago I wrote Admiral Hughes-Hallett asking him to search his memory again. He did something better: he consulted his diary, which was not available to him when I first discussed the matter with him. The diary established the date of the meeting as 30 June 1942. The reason for Mr. Churchill's concern over Dieppe at that moment was the recent disaster at Tobruk; he was, I gather, troubled by the possibility of another failure.

With all good wishes and again many thanks,

Yours sincerely,

C.P.S.

(C.P. Stacey) Colonel,

Director Historical Section 
A.B. Acheson, Esq., C.M.G.,

Cabinet Office,

Great George Street,

London, S.W.1,

England.

\title{
Document 4
}

\section{C.P. Stacey to A.B. Acheson, 12 March 1953, RG 24, box 31893, HQC 1450- 34/336, pt. 2, Library and Archives Canada.}

\author{
Historical Section, \\ Army Headquarters, \\ Ottawa, Canada, \\ 12 March 1953.
}

Dear Mr. Acheson,

I am troubling you with a query by way of following up the very useful information given in your letter of $19^{\text {th }}$ January last.

The memorandum accompanying your letter remarks that in April 1942 the War Cabinet concluded that raiding operations should be undertaken during 1942 to test the German defences, as a preliminary to more extensive operations later.

It would be useful to me to know the exact date in April 1942 on which this decision was taken.

I find that on 14 April 1942 the C.-in-C. Home Forces, the A.O.C.-in-C. Fighter Command and the Chief of Combined operations, who had been directed to plan operations designed to divert German air forces to the West, reported that, leaving aside the question of air action alone, a series of medium-sized raids was the only practicable solution. They asked the Chiefs of Staff to endorse this policy and authorize the necessary priorities. Later developments indicate that the chiefs of Staff did this, but we seem to have no record of when they did it or the precise terms of the decision. I should like to know these things, if possible.

These two queries are, you will observe, closely connected in time and content. It seems possible that the chiefs of 
Staff, on receiving the recommendation on 14 April, sent a recommendation to the War Cabinet, with the result described in your memorandum. At any rate, I should be grateful for any clarification which policy allows you to give me in this matter. In order to make our account of the preliminaries of Dieppe as complete as possible, we are anxious to have an exact picture of the chronology of decisions.

I hope that dealing with these inquiries will not involve a great deal of trouble for you and your staff.

With all good wishes,

Yours sincerely,

C.P.S.

(C.P. Stacey) Colonel,

Director Historical Section

A.B. Acheson, Esq., C.M.G.,

Cabinet Office,

Great George Street,

London, S.W.1,

England.

\section{Document 5}

Acheson to Stacey, 1 April 1953, RG 24, box 31893, HQC 1450-34/336, pt. 2, Library and Archives Canada.

CABINET OFFICE,

Great George Street,

London, S.W.1.

$1^{\text {st }}$ April, 1953.

My dear Colonel,

I have now completed my researches into the questions raised in your letter of the $12^{\text {th }}$ March, and I think the best thing I can do is to send you the enclosed day-by-day summary. You will see that the War Cabinet conclusion that raiding operations should be undertaken to test German defences was reached on the $29^{\text {th }}$ April. But it was not reached as a result of the $14^{\text {th }}$ April report by the C.-in-C. Home Forces, the AOC-in-C Fighter Command and the Chief of Combined operations, which was never formally considered by the 
Chiefs of staff at all, and never came before cabinet. It derived from the proposals put forward by the Americans.

What then was the origin of the conception of the Dieppe raid? Here is the conclusion to which my researches have led. Combined Operations Headquarters made it their business to keep under continuous review and examination possible targets for raids and possible areas in which raids, great or small, could be undertaken. Though at first limited to very small raids, they knew that our resources of manpower and materials (in particular landing craft which at this time was a bottleneck) were growing. They knew too that both Ministers and Chiefs of Staff were anxious that raids on a comparatively large scale should be undertaken as soon as circumstances and available resources permitted. They did not therefore limit their consideration of possible targets and areas to those suitable only for small raids.

In the course of this continuous process of consideration and examination, information and intelligence about Dieppe began to be collected in 1941. By April 1942 this material had been sufficiently assembled to enable planning for a definite raid (i.e. on Dieppe) to start, and I have ascertained that the first meeting at Combined Operations Headquarters to consider a definite plan took place on the $3^{\text {rd }}$ April. This establishes that the original conception was not the direct result of the American proposals. But by the $9^{\text {th }}$ April, when General Marshall first met the Chiefs of Staff, the chief of Combined Operations was aware that the idea of a major raid on Dieppe would be fully in line with the American ideas, and by midnight on the $14^{\text {th }}$ April (the Defence Committee met at 10.0 p.m. on that day) that the American ideas had been accepted as a general policy by the Defence Committee and were therefore virtually certain to be approved by the War Cabinet. And this no doubt gave him confidence and encouragement to press forward with his planning for Dieppe.

This is the picture, as I see it. On paper the general policy as regards raids was on the $3^{\text {rd }}$ April still governed by the Chiefs of Staff directive of the 13 th February. But this directive was superseded in a matter of days by the approval given by the Defence Committee to the American policy, and the Dieppe raid fell clearly within that policy. The only evidence which might at first sight conflict with these conclusions is the statement in the Chiefs of Staff directive of the $18^{\text {th }}$ April that "We have already approved" a policy of large-scale raids in the summer of 1942. That, 
on the face of it, reads a trifle oddly, if in fact the position was that this policy had been approved only four day earlier by the Defence Committee as part of the new American proposals. I have therefore had exhaustive research made to ascertain whether, independently of the American proposals, the Chiefs of Staff had approved a new and wider raiding policy between the $13^{\text {th }}$ February and the $9^{\text {th }}$ April. I can discover nothing. I think that the answer probably lies in the conversation which General Marshall and his planning officers had has with the Chief of Combined Operations between the $9^{\text {th }}$ and $10^{\text {th }}$ April. The results of these conversations were not recorded. They were reported orally to the Chiefs of Staff on the $10^{\text {th }}$ April. But the statements made by the C.I.G.S. at the Chiefs of Staff meeting on the $14^{\text {th }}$ April, and by General Marshall at the Defence Committee meeting on the same day, show quite clearly that the chiefs of Staff had by that time accepted a policy of intensive raiding. I think this must be the explanation of the particular phraseology used in the Chiefs of Staff directive of the $18^{\text {th }}$ April.

I think there is only one other thing I need add and that is to emphasise that running right through all the discussions on raiding policy which proceded the visit of General Marshall and Mr. Harry Hopkins, and lying at the root of the whole policy which these two brought over with them, was a realisation of the urgent need to relieve the pressure on the Russians. This, so far as the American proposals are concerned, is I think sufficiently demonstrated by President Roosevelt's letter to Mr. Churchill on the $3^{\text {rd }}$ April, which is reproduced in Chapter XVIII, page 281, of Mr. Churchill's Volume IV.

I am sorry that it has taken me a little while to elucidate these matters, and I must also apologise for the fact that I am still unable to write to you about your last question - namely whether there are any records which throw light on the apparent desire of the British Government that Canadian formations should remain in Britain, and whether there was any discussion in the summer of 1942 of allotting Canadian formations to Operation TORCH. It is not that a great deal of work has not been done on this matter. The position is quite simply that we have at present been unable to find any British records bearing directly on either point. On the other hand, the records which might contain something are so voluminous and the staff at my disposal is so small, that we have not yet exhausted every conceivable source. We are, however, on the last lap, and I very much hope to be in a 
position to write to you on these points within the next two or three weeks.

With all good wishes,

Yours sincerely,

[signed] A.B. Acheson

Colonel C.P. Stacey,

Historical Section,

Army Headquarters,

Ottawa,

Canada

RAIDING OPERATIONS POLICY, 1941-1942

Plans for raids on the continent began to be made early in 1941. The general picture throughout the last six months of the year is one of pressure from the Prime Minister and other Ministers (e.g. Mr. Eden, who was approached by M. Maisky in July) for raids on a substantial scale, which the Service authorities were obliged to resist owing in the main to lack of material resources. At first, raids were limited to reconnaissance patrols, but in October 1941 the Chiefs of the staff authorised a general policy of raids on the French, Dutch and Belgian coasts. On the $7^{\text {th }}$ November 1941 they directed that the question of mounting a large-scale raid, employing one or more divisions, in the spring of 1942 should be considered. But the report they received indicated that a raid on this scale could not be launched before the autumn, and they abandoned the project, merely directing that it should continue to be studied and that meanwhile a vigorous policy of small raids should be continued. That was on the $13^{\text {th }}$ February, 1942 .

\section{SLEDGEHAMMER}

On the $17^{\text {th }}$ March 1942 the Chiefs of Staff considered a proposal put to them by the Joint Planners, the object of which was to relive Russia by drawing off German forces from the Eastern front, and as the means to that end to establish and attempt to maintain a permanent bridgehead in Europe - "Operation Sledgehammer". The Chiefs of Staff invited the Joint Planners to consider the matter more generally and, without committing themselves necessarily to the establishment of a bridgehead, to review the possibilities of causing maximum destruction to Germany during the period May-July 1942 with the object of relieving 
pressure on the Russian front. On the $19^{\text {th }}$ March the Joint Planners reported against any sustained land operations being undertaken so soon, and recommended that an attempt should be made to compel the Germans to employ their air force continuously in active operations in the West, so as to reduce German air support on the Eastern front. For this purpose they suggested that fighter sweeps and daylight bombing was not enough, and that a major land operation should be "simulated", since the threat of a large-scale land operation might itself achieve the object in view, or a major raid be undertaken. They suggested that both should be planned. On the $21^{\text {st }}$ March the Chiefs of Staff issued a directive to the C.-in-C. Home Forces, the AOCin-C. Fighter Command, and the Chief of Combined Operations to plan operations with a view to making the Germans continuously employ air forces in active operations, and to cause protracted air fighting in the West under conditions advantageous to ourselves, in order to reduce German air support in the Eastern theatre. On the $27^{\text {th }}$ March these three produced an appreciation which stated that in their opinion the limited object set could be achieved by air action alone, but that, if circumstances forced us to take military action, the Pas de Calais area was, at first sight, the most suitable. On the $28^{\text {th }}$ March the Chiefs of Staff asked for a further examination of the plan for military operations in the Pas de Calais area. This was forthcoming on the $7^{\text {th }}$ April. It suggested that an operation designed to establish and hold a bridgehead in the Pas de Calais area was practicable, but that the risks would be serious. It would call for a high proportion of the troops in the U.K. that, if it failed - and failure must be contemplated if the Germans diverted major forces against the bridgehead, or if maintenance difficulties could not be overcome - the defence of the U.K. would be seriously imperilled. The Chiefs of Staff felt at their meeting on the $8^{\text {th }}$ April that an operation of this kind could not be contemplated, and they invited the authors of the report to consider what action was practicable to help Russia if she were hard pressed by the Germans in the summer. This resulted in a report on the $14^{\text {th }}$ April, which recommended a policy of raids on as large a scale as possible. The report stated that "investigation into one medium sized raid has already begun". (This was probably Dieppe) It was not however considered by the Chiefs of Staff, as it was superseded by the discussions with the Americans. 
Meanwhile General Marshall and Mr. Harry Hopkins had arrived to discuss future war policy. For present purposes the American plan can be summarised as directed to: -

(a) a full-scale invasion of Europe in 1943;

(b) preparations for some "Emergency Operation" on the continent at an earlier date to help the Russians, or alternatively to take advantage of a break in German morale;

(c) meanwhile a policy of raids on the continent.

The Chiefs of Staff had preliminary discussions with General Marshall and Mr. Harry Hopkins on the $9^{\text {th }}$ April. At this meeting, according to the record, General Marshall did not particularly emphasise the need for an active raiding policy. The C.I.G.S., inter alia, explained that we were doubtful whether anything could be achieved by land operations on a major scale in 1942, but that we were executing a number of raids: and the chief of Combined Operations "described the policy under which we were conducting raiding operations" and gave details of various raids. (i.e. raids already carried out, and raids being planned.) It was arranged that there should be immediate consultations between General Marshall and his Planning Officers and the Chief of Combined Operations. On the $10^{\text {th }}$ April the Chiefs of Staff had a discussion among themselves, the record of which says nothing about raiding policy or raids, but says that the Chief of Combined Operations reported the results of his conversations with General Marshall and his Planning Officers.

On the $14^{\text {th }}$ April the Chiefs of Staff had a further meeting with General Marshall, at which the C.I.G.S. made a long statement in the course of which he said that we intended to intensify both the scope and frequency of our seaborne and airborne raids on the enemy's coastline.

Later on the same day (14 ${ }^{\text {th }}$ April) General Marshall and Mr. Harry Hopkins were present at a meeting of the Defence Committee of the War Cabinet, at which General Marshall said that the Americans and British were in complete agreement (inter alia) as to the necessity of expanding the programme of raids. At this meeting the American proposals were generally accepted.

On the 18th April the Chiefs of Staff issued a directive on responsibility for planning on the basis of the American 
proposals. This started by stating that the Defence Committee had given general approval to the American proposals, which would call inter alia for "a series of raiding operations to be carried out in the summer of 1942": and then said "We have already approved a policy of raids to be undertaken in the summer of 1942 on the largest scale that the available equipment will permit". It laid responsibility for planning these raids on the chief of Combined Operations in consultation with the C.-in-C. Home Forces.

On the 29th April the War Cabinet met to consider the American proposals, and in the course of a preliminary explanation of them it was stated that preparations already in hand would include raids on an increasingly large scale to test the German defences. The War Cabinet generally endorsed the American proposals. 